Session 2793

\title{
Team- Based Engineering Design Course for Engineering Freshmen
}

\author{
Subhi M. Bazlamit \\ Department of Civil Engineering/Ohio Northern University
}

The curriculum at Ohio Northern University includes two introductory engineering courses for the incoming freshmen class. These courses are intended to introduce the basic analytical and problem solving skills to students through an actual team-based design experience. The students are introduced to the engineering approach to design and problem solving starting from defining a problem, gathering pertinent information, generating multiple solutions, selecting a feasible solution and verifying and implementing the final solution.

In the Fall Quarter, the freshmen class is enrolled in GE 101 course, Fundamentals of Engineering where students are introduced to engineering problems and basic computer skills involving MS Word and MS Excel. In the Winter Quarter, the students are enrolled in the GE 102, Problem Solving and Computer Aided Drafting (CAD) course. In this course, the students are normally divided into design teams and each team is charged with an engineering design problem. Design problems are those involving the design of a small device used to perform a certain function such as a produce launcher, a tool, or a foot-operated paper towel dispenser. Each team is expected to build a working model of their design in the workshop. Each team will submit a proposal and a project schedule identifying all work items needed to complete the design experience by the end of the quarter. Weekly written and oral progress reports are also required from each team. Students are also required to maintain a design folder in which all relevant correspondence, team meetings and design calculations are kept.

The design is normally constrained by size and cost and other considerations that may be applicable depending on the problem. This design experience allows students the opportunity to work in teams during their first year of enrollment. It also emphasizes the importance of graphical, written and oral communications in the engineering discipline.

This paper presents an overview of the process and attempts to document the associated observations from this team-based design experience.

\section{Introduction}

The engineering industry is very competitive in nature. Moreover, most engineering projects require the collaboration of many individuals ${ }^{1}$ within the same engineering firm to address problems and formulate feasible solutions. This class addresses this nature of the engineering industry. It allows the freshmen students an opportunity to experience the engineering design process from writing proposals to construction of a working model. 
The syllabus for this class covers a period of ten weeks and the meetings for this course consist of two weekly fifty-minute lectures and a two-hour laboratory session in the computer room. Two textbooks are used in this course; one is primarily used to introduce the engineering design process and the other to help students learn the Computer Aided Drafting (CAD) ${ }^{2,3}$. The computer session is used primarily for introduction of CAD while the other two class lectures are used for instructions related to the design and problem-solving portion of this course. A typical class of freshmen students in this course is made of students from Civil Engineering, Electrical Engineering, Computer Engineering and Mechanical Engineering majors. The weekly course activities are divided according to Table 1.

Table 1: Weekly Lecture Activities

\begin{tabular}{|c|c|}
\hline Week No. & Lectures \\
\hline 1 & $\begin{array}{l}\text { Introduction and Forming } \\
\text { Design Teams } \\
\text { Generating a List of Design } \\
\text { Problems }\end{array}$ \\
\hline 2 & $\begin{array}{l}\text { Selection of Design Problem } \\
\text { Statements } \\
\text { Request for Proposals }\end{array}$ \\
\hline 3 & $\begin{array}{l}\text { Preparing Propo sal } \\
\text { Document and Proposal } \\
\text { Presentation }\end{array}$ \\
\hline 4 & $\begin{array}{l}\text { Workshop Orientation and } \\
\text { Working Drawings } \\
\text { Problem Statement } \\
\text { Refinement and Decision } \\
\text { Matrix }\end{array}$ \\
\hline 5 & $\begin{array}{l}\text { Introduction to Basic } \\
\text { Material Properties } \\
\text { Construction of Working } \\
\text { Model }\end{array}$ \\
\hline 6 & $\begin{array}{l}\text { Workshop Operations and } \\
\text { Weekly Progress Report }\end{array}$ \\
\hline 7 & Midterm Exam \\
\hline 8 & Construction Continues \\
\hline 9 & Working Model Testing \\
\hline 10 & $\begin{array}{l}\text { Final Report and } \\
\text { Presentation }\end{array}$ \\
\hline
\end{tabular}

\section{Forming Design Teams}

The instructor forms design teams during the first week while attempting to maintain diversity of 
discipline in each design team. Team size normally varies between three to four students. Once teams are selected, the students are then introduced to the concept of Statement of Qualifications (SoQ). Teams are required to prepare a SoQ brochure based on their current resumes of team members and expanding from that to highlight prior engineering experiences if any. Experience related to building and construction of working models or any hands on experience may be included in these brochures. Student design teams are encouraged to include experiences that are relevant to the engineering problem statement that they are interested in.

\section{The Engineering Design Process}

This course regards the engineering design process as a five-step process ${ }^{2}$ :

1. Problem Statement

2. Gathering Pertinent Information

3. Generating Multiple Solutions

4. Selecting a Feasible Solution

5. Building, Testing and Verifying Working Model

The initial proposal in this course addresses the first three steps while steps 4 and 5 are accomplished following the acceptance of design proposals.

\section{Problem Statements}

A list of design ideas is generated in the second lecture of classes during the first week of the course. This session is a brainstorming session on ideas facilitated by the instructor. Each design team is given 15 minutes to come up with three design ideas for devices, tools or gadgets that can be used in one's daily life. These ideas are limited to items that can be built in the workshop over the span of six weeks of eight-man hours in the workshop and with an anticipated material cost of less than one hundred dollars. Such ideas may include automatic pet feeders, potatoe launchers, marshmallow toasters, etc. Each team will then write on the board their design ideas and elaborate on them to explain to the rest of the class the features they intend to have in their design idea.

Table number 2 lists the design ideas generated by the students in class this year. 
Table Number 2: A list of Design Ideas Generated by Student Teams

Design Idea

Automatic chalk board cleaner

Inline skeet thrower

Smokeless ashtray

Remote-controlled hovercraft

Non-burning popcorn popper

Pneumatic pizza slicer

Automatic focus projector

Motion-sensing paper towel dispenser

Flaming marshmallow Gatling gun

Cat disperse (sound wave gun)

Controlled potato gun

Automatic blinds

Automatic folding table

Drug dispenser

Automatic pet-feeder

Automatic Post-It note dispenser

A produce launcher

Rocket/launch system/launch pad/camera
Design Idea

Self-operating vacuum cleaner

Hot water stabilizer

Frozen marshmallow gun

Remote-controlled window blinds

A marshmallow launcher

Poker chip distributor

One- to four-person pedal car

Lego collector

Controlled catapult

Solar-powered lawnmower

Anti-theft gadgets

Disposable camera

Card shuffler

Remote-controlled gas-powered car

Solar-powered remote-controlled car

Pancake-flipper

Can crusher

Pneumatic can crusher

The students are then asked to meet as a group and decide on one idea that they would like to adopt as a design problem for this class. Once they select an idea, then they are required to formulate a problem statement describing the intended design including defining dimensions, design constraints and the criteria that would be used later to select among a list of viable solutions that they will generate. As the case with design problems, the number of possible solutions is relatively large and it can only be reduced to a manageable number of viable solutions once design constraints are applied. Then, this list of viable solutions can be further reduced to one single feasible solution by applying the criteria used in evaluating multiple viable designs through the technique of decision matrices. Common criteria may include cost, ease of construction, durability and any other criteria consistent with the nature of the design problem.

\section{Preparation of Initial Proposals}

Once the problem statements are properly and reasonably formulated, then each design team is asked to prepare a formal design proposal covering the first three steps of the design process. Steps two and three of this process may include researching the web for existing solutions and determining the pros and cons of such solutions. In most cases, the students may end up adopting an existing solution with some major modifications as their possible design. In certain instances, the students will use the result of their research to demonstrate consumer dissatisfaction with existing solutions and come up with a totally new design of their own. Once this research is 
completed, the students are ready to put together a design proposal to be submitted to the client. In the proposal, the students are required to include a schedule of working tasks using MS Project software, and a breakdown of design cost to provide their engineering services. At this point, material and production costs are not required and are normally only required following the construction of final working model along with a marketing analysis to indicate the retail price of new design and an estimated number of units to be produced to break even. Students submit a copy of their proposals attached to a transmittal letter addressed to the instructor. In addition, the teams will present their proposals in class using a PowerPoint presentation. These presentations normally cover the first three steps of the design procedure.

\section{Building the Working Model}

In week 4, the students participate in a workshop safety orientation session in which, safety concerns and requirements are introduced to them. In addition, they will also be introduced to the available machinery and materials in the shop. In most cases, students are encouraged to utilize readily available materials in the shop such as steel, wood and plastic pipes. However, in certain instances, the college will order in special materials for certain projects if needed. During this session, the importance of working drawings is emphasized and this usually causes design teams to start transforming their design ideas from conceptual drawings to actual working drawings. The working drawings normally will specify the material and the dimensions of the design and is produced using the CAD software. Students are normally supervised while working in the shop and the workshop technician attends the shop at all times. If the technician is not available to supervise the design teams working in the shop, the supervisor will assume this responsibility to ensure students safety and to provide the assistance needed on the operation of machinery. Student teams will schedule a time for working in the shop in coordination with the workshop technician. This scheduling will allow an efficient management of shop resources to better serve the student needs without compromising safety.

\section{Progress Reports}

On a weekly basis, student teams are required to present an oral progress report in class. These reports include activities accomplished during the past week and activities to be performed in the following week. In addition, student teams also indicate how these activities are consistent with the initial project schedule to demonstrate the ability to complete the project on time. As a result of the nature of actual workshop activities, some modifications to the original design may be required and the students are free to modify their initial designs provided they have reasonable arguments for doing so. Such modifications in most cases may include changes in material selection and in dimensions in most cases. Usually, these modifications are the result of working model testing and validation phase. All modifications are documented along with the reasoning that prompted such modifications and are added to the team's design file for future reference.

\section{Final Report and Presentation}

In the final week of classes, student teams are required to submit a final report and to give a fifteen-minute PowerPoint presentation, which includes an actual demonstration of their working 
model in class. Some teams include a video presentation of the demonstration if the demonstration cannot be performed in class, as the case would be for compressed-air potato launchers for example. The report is supposed to document the entire design process and normally would include a marketing analysis of the design. Students are encouraged to seek the assistance of professors in the Business College in preparing their marketing analysis.

\section{Course Assessment:}

At the conclusion of the course this year, two sections of this class participated in an assessment survey. A total of fifty students responded and the summary of their responses is shown in Table Number 3.

Table Number 3: Summary of Student Assessment (\%)

1. In your own opinion, how well do you think you did on the following steps of the design process?

\begin{tabular}{|l|l|l|l|l|l|}
\hline Design Steps & $\begin{array}{l}5 \text { Very } \\
\text { Good }\end{array}$ & 4 Good & $\begin{array}{l}\text { Fair } \\
\text { Poor }\end{array}$ & $\begin{array}{l}1 \\
\text { Very } \\
\text { Poor }\end{array}$ \\
\hline Problem statement with constraints and criteria & 52 & 44 & 4 & & \\
\hline Collection of pertinent information & 40 & 50 & 10 & & \\
\hline Generating multiple solutions & 40 & 42 & 18 & & \\
\hline $\begin{array}{l}\text { Selection of a feasible solution using a decision } \\
\text { matrix }\end{array}$ & 58 & 28 & 14 & & \\
\hline $\begin{array}{l}\text { Construction of the final design and modifications to } \\
\text { original design }\end{array}$ & 48 & 40 & 10 & 2 & \\
\hline
\end{tabular}

2. In your opinion, how well do you think you have done in the following portions of this course?

\begin{tabular}{|l|l|l|l|l|l|}
\hline Portion & $\begin{array}{l}5 \\
\text { Very } \\
\text { Good }\end{array}$ & $\begin{array}{l}4 \\
\text { Good }\end{array}$ & $\begin{array}{l}\text { Fair } \\
\text { Poor } \\
\text { Very } \\
\text { Poor }\end{array}$ \\
\hline Team Letter Head and Logo & 56 & 31 & 13 & & \\
\hline Team Brochure & 44 & 39 & 11 & 6 & \\
\hline Proposal Preparation & 28 & 51 & 19 & 2 & \\
\hline Oral Presentation of Proposal & 45 & 35 & 18 & 2 & \\
\hline Building a working prototype & 44 & 46 & 6 & 4 & \\
\hline Preparation of Final Report & 41 & 46 & 9 & 4 & \\
\hline Final Oral Presentation & 41 & 45 & 9 & 5 & \\
\hline
\end{tabular}

3. How do you rate the following aspects of teamwork?

\begin{tabular}{|l|l|l|l|l|l|}
\hline Aspect & $\begin{array}{l}5 \\
\text { Very } \\
\text { Good }\end{array}$ & $\begin{array}{l}4 \\
\text { Good }\end{array}$ & $\begin{array}{l}\text { Fair } \\
\text { Poor }\end{array}$ & $\begin{array}{l}1 \\
\text { Very } \\
\text { Poor }\end{array}$ \\
\hline Team Interaction & 56 & 25 & 17 & 2 & \\
\hline Team Leadership & 50 & 33 & 17 & 2 & \\
\hline Team Effectiveness and Productivity & 40 & 40 & 16 & 4 & \\
\hline $\begin{array}{l}\text { Overall team experience } \\
\text { (5: Enjoyed it, 1: Hated it) }\end{array}$ & 47 & 41 & 4 & 6 & 3 \\
\hline
\end{tabular}

4. Having completed this course, do you think that you have a better understanding of the engineering design process? Yes $\underline{95 \%}$, No $\underline{5 \%}$ 
The students' responses suggest that the majority of students had understood and were able to apply the steps of the engineering design process in their projects. In addition, positive responses were also given in reference to working in teams and various aspects of project work including proposal preparation, oral presentations and the construction of the working models of their designs. About $95 \%$ of the students indicated that they had a better understanding of the engineering design process at the conclusion of this course.

\section{Comments and Conclusions}

This approach to teaching engineering design to freshmen students has proven to be an appropriate approach that provides the students with an opportunity to work in teams through a hands-on experience in the workshop. It allows them to experience real-world aspects of the engineering design process. It also emphasizes the importance of graphical communications and design documentation. Communication skills are an integral part of this process and the students are presented with opportunities where these skills can be utilized and tested. Considering that the analytical skills of engineering freshmen in the second quarter of college are at best limited, most design teams seem to follow an incremental approach to the design problem where small incremental steps are initially taken. If these steps were proven to be effective, then additional steps are then pursued until the final goal is accomplished. From a student prospective, the ability to transfer ideas from drawings to life allows them to enjoy the hands-on aspect of this process. Student responses to the assessment survey seem to indicate that the majority of the students thought of this course as being beneficial in providing them with a better understanding of the engineering design process.

\section{Bibliography}

1. Oberlender, G., “Project Management for Engineering and Construction”, $2^{\text {nd }}$ ed., McGraw -Hill Companies, New York, 2000.

2. Howell, Steve K., "Engineering Design and Problem Solving” $2^{\text {nd }}$ ed., Prentice Hall, 2002.

3. Metz, Terry D., "AutoCAD 2002- A Building Approach, Book2: Taking Command”, Prentice Hall, 2003.

\section{BIOGRAPHICAL INFORMATION}

SUBHI M. BAZLAMIT is an associate professor of Civil Engineering at Ohio Northern University in Ada, Ohio. Dr. Bazlamit is married and has one seven-year-old son "Mohammed". Dr. Bazlamit had taught the tran sportation engineering courses, surveying, urban planning and introductory engineering courses for freshmen students at Ohio Northern University. In addition, he also teaches the senior capstone design course in the department of Civil Engineering 